\title{
新潟県の地すべりとその環境 \\ The land slide of Niigata Prefecture and its environment
}

\author{
山野井徹* 石黒重実** \\ 布施弘***神田章**** \\ Tohru YamanoI, Shigemi Ishiguro, \\ Hiroshi FusE, Akira KANDA
}

\section{1.はじめに}

新潟県は，日本に括ける地すべりの多発県であること は周知のと招りである。歷史泟残るものも多数あるが， そのらちでも特に超大地すべりとしては，宝暦元年（17 51年）の名立地すべり（一部落全部海中に没し, 死者 428 人), 天明 3 年（1783年）の東野名地すべり（耕地 $30 \mathrm{ha}$ が 流出)，天保 3 年(1833年）の中尾地すべり (一部落壞隇) などをあげることができる1)。また，戦後の大地すべり としては，棚口地すべり（昭和 22 年 5 月，人家 80 戸倒 壤），樽田地すべり（昭和 32 年 4 月，死者 18 人），地獄 谷地すべり (昭和 33 年 12 月，死者 2 人)，東中野俣地す ベり（昭和 37 年 3 月，死者 6 人)，松之山地すべり（昭 和37年12月～，600ha，人家296戸被苂)，能生小泊地す べり (昭和 38 年 3 月, 列車転覆, 死傷者 23 人)，水沢新 田地すべり（昭和 44 年 4 月，死者 8 人）等をあげるこ之 ができる。そして，今年も多くの地すべりが発生し，住 民の幾多の財産が失われた。このような地すべりの防止 対策として新潟県全体で40億円余り（昭和49年度）の地 すべり防止事業がなされるに至っている。われわれは， このような地すべりを可能な限り防止すべく努力してい る。それには，地すべり現象を自然の中で，より正確に とら觉力を急ってはならぬと信ずる。かかる認識に たち，筆者らは，新潟県に扔ける地すべりと，自然環境 との関係を追求した。すなわち，地すべりの外的要因の 主となる気象との関係, 内的な要因である地殸変動, 地 質との関係，そして地すべりをも含めた侵食作用の過程 としての地形との関倸についてそれぞれ求め，地すべり が新潟県全域からみて，いかなる特質をもつ地飞生ずる かについて言及した。

この報告をするに当り, 新潟大学教養部地学教室の津田 禾粒教授, ならびに同大学理学部地質鉱物学教室の学生 諸氏からは多大な御協力を得た。ここに記して謝意を表 する次第である。

\footnotetext{
* 新潟県治山課

** 新堨県治山課設課(元同砂防課),

**** 河川開発課(元同砂防課)

**** " 農地建設課
}

\section{2. 法}

この報告で扱う「地すべり地区」とは，地すべり現象 が顕著にみられ，地すべり等防止法に基づき指定された 「地すべり防止区域」と, 昭和 45 年 46年に，建設省扔 よび農林省（林野庁, 棈造改善局）が歩調を合わせ, 全 国の都道府県の協力により調查した「地すべり危険地域」 をいら。この地すべり危険地域は, 空中写真, 地形図の 判読，古文書や老人の口伝，その他公的機関による調査 等を参考にし，現に地すべりの危険性の大きい区域を， $1 / 5$ 万地形図に既指定地とともに図示することにより求 められたものである。したがって，ここで扱ら地すべり 地区は，単に空中写真等の判読によって得られた標本と は違い，現実に動いているか，またはすべる危険が非常 に大きい区域である。このようにして得た地すべり地区 1593か所についての概要を図－1に示し，以下に述べる 諸区分の図により地すべり地区との関係を求めた。

最大積雪深区分：新潟地方気皇台・新潟県が発行する 新潟県農業気像月報 $(1964 \sim 1973)^{2)}$ より求めた新潟県 各地の最大積雪深の年平均值から, 最大雪積等深図を作 成したもの使用した。

地殼変動区分：第四紀地殼変動研究グループ (1969) の作成した集成隆起沈降量図 ${ }^{3)}$ を一部修正した図面を使 用した。

地質区分：新潟罧発行の $1 / 5$ 万地質図拈よび，新潟大学 理学部に保存（未公表資料も含さ）されている地質図に より, 地質時代区分, 岩質区分, 地質構造区分, 地層之 地すべり方向区分をそれぞれ行なった。

谷密度区分：国土地理院発行の $1 / 5$ 万地形図の各辺を 10等分して得た各方眼の 4 辺と交わる谷筋を数えた経済 企画庁の $1 / 20$ 万土地分類調查（1968）に拉沪る作業図を 使用した。

起伏量区分：上記に同じ地形図の各辺を10等分して得 た各方眼内の最高点と最低点との標高差を求めた同作業 図を使った。

傾斜度区分：上記に同じ地形図の各辺を20等分して得 た各方眼内で，地形，傾斜の特徵を最もよく表している 


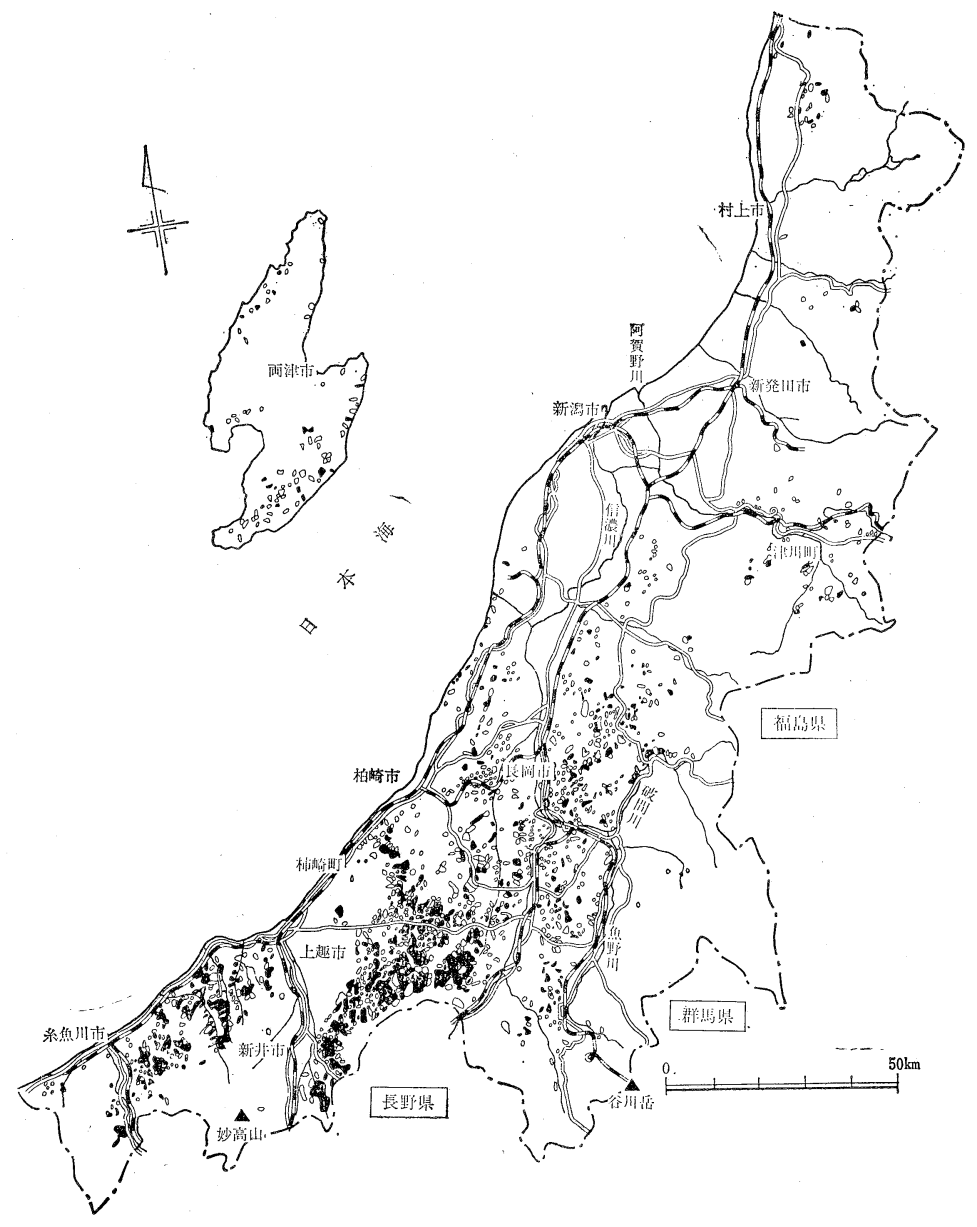

図-1 新潟県の地すべり地区概要図 黑色は地すべり防止区域(指定地), 白始きは地すべり危険区域
降水がもたらされることが特徵と なっている。しかし，雪は県内一 様浲るわけではなく, 日本海沿 岸の平野部から越後山脈の方向へ 增加する傾向がある。

表-1は, 10年間の最大積雪深の 平均值を 6 段階に区分し，地すべ り地区との関係をまとめたもので ある。ここに示すように，最大積 雪深区分が $201 \sim 300 \mathrm{~cm}$ の地域内 に地すべり地区は 605 地区（全地 区数の $38 \%$ ）と最も多く, 次いで 101 200cmの区分域内に 451 地区, 301 400 cm には 342地区がある。 そして, これら 3 つの区分の地域 (101 400cm) 亿全地すべり地区 数の $88 \%$ 存在している。また最大 積雪深により区分した区域内で地 すべり面積の占める割合は，201 $\sim 300 \mathrm{~cm}$ の地域では, $14.8 \% か ゙$, $301 \sim 400 \mathrm{~cm}$ では, $10.4 \%$ ぞれ ぞれ地すべり地となって掠り，他 の積雪区分域と比べて著しく地す ベり面積の占める割合が高い。た だし，この現象から $201 \sim 400 \mathrm{~cm}$ の最大積雪区分域が最も地すべり を起し易いと考光ることはできな い。なぜなら他県のこの程度の積 雪深が必ずしも地すべり区域の多 い所となっていないからである。
地区の水平距離と高度差から, 傾斜度を算出した同作業 図を用いた。

以上の諸区分図と, 個々の地すべり地区との関係を, 1 地区 1 枚のカードに表現した。ここまでの作業は, 新 潟県と新潟大学が協同で行なった。そしてこれらのデー タの集計に当っては筆者らが分担して行なった。すなお ち, 最大積雪深区分, 地款変動区分は山野井が, 地筫区 分は布施が, そして谷密度区分, 起伏量区分, 傾斜度区 分については神田がそれぞれ担当し, 気象 と地すべり発生との関係については石黒と 山野井がデータの整理に当つた。さらに, それぞれの分担を各自が執筆後, 全体を山 野井がまとめた。

\section{3. 新潟県の気象と地すべり}

\section{3-1 最大積雪深と地すべり}

新潟県の気候は, 裏日本気候の典型的な 地方の 1 つであり, 冬には雪による多くの
したがって, 最大積雪深以外の要因が主となって, 地す ベり地区が密集している地域と, 上記 $201 \sim 400 \mathrm{~cm}$ 区分 域とが一致していることを, 融雪水が地すべり発生に与 党る影響という観点に掠いて重視したい。

\section{3-2 新潟県の気象と地すべりの発生}

新潟目の気象と地すべり発生との関連を述べるに当り, まず, 新潟県の1949年 (昭和24年) からの月別の地すべり 発生件数を表 -2 亿示す。この発生件数の月別平均（25

表-1 地すべりと最大積雪深との関係

\begin{tabular}{|c|c|c|c|c|c|c|c|c|}
\hline \multirow[b]{2}{*}{ 区 分 } & \multicolumn{5}{|c|}{ 地すべり 地 区 } & \multirow{2}{*}{ 全 } & \multirow{2}{*}{ 積 } & \multirow{2}{*}{$\begin{array}{l}\text { 地すべり } \\
\text { 地区面積 } \\
\text { の占有率 }\end{array}$} \\
\hline & 区 & 数 & 面 & 積 & $\left|\begin{array}{l}1 \text { 力所当 } \\
\text { の平均面積 }\end{array}\right|$ & & & \\
\hline $0 \sim 100 \mathrm{~cm}$ & 167カ所 & $10.5 \%$ & 6,584ha & $8.7 \%$ & 39. $4 \mathrm{ha}$ & $3,706 \mathrm{~km}^{2}$ & $29.5 \%$ & $1.8 \%$ \\
\hline $101 \sim 200$ & 451 & 27.2 & 17,875 & 23.6 & 39.7 & 3,930 & 31.2 & 4.6 \\
\hline $201 \sim 300$ & 605 & 38.0 & 29,840 & 39.3 & 49.3 & 2,021 & 16.1 & 14.8 \\
\hline $301 \sim 400$ & 342 & 21.5 & 19,760 & 26.0 & 57.8 & 1,909 & 15.2 & 10.4 \\
\hline $401 \sim 500$ & 28 & 1.8 & 1,796 & 2.4 & 64.1 & 899 & 7.1 & 2.0 \\
\hline $501 \sim$ & 0 & - & 0 & - & - & 112 & 0.9 & - \\
\hline 計 & 1,593 & 100.0 & 75,875 & 100.0 & 47.6 & 12,577 & 100.0 & 6.0 \\
\hline
\end{tabular}


地すべりVol.11, No.2 (通巻 第38号)

表-2 1949年から新潟県に発生した地すべり件数（月別）

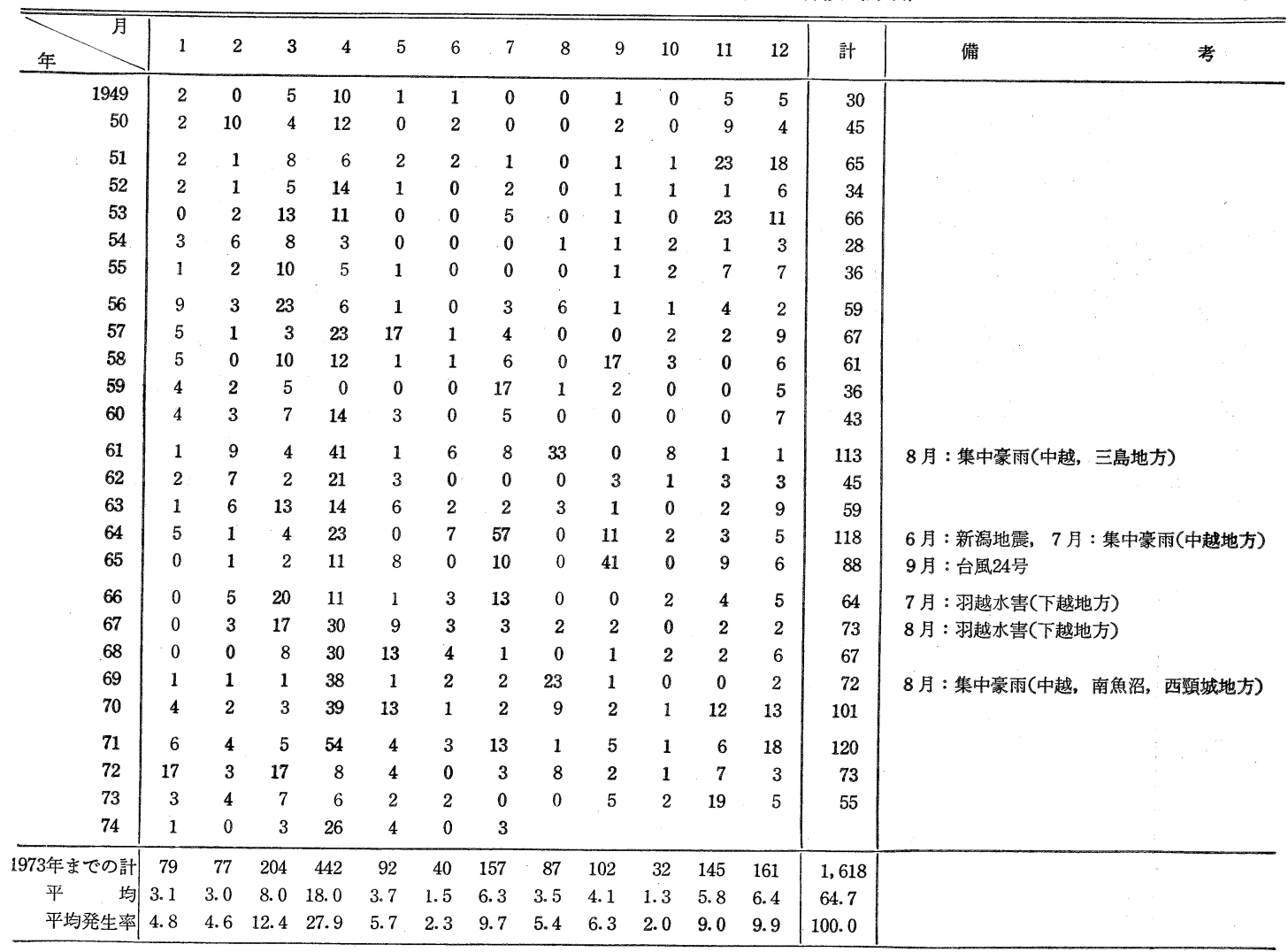

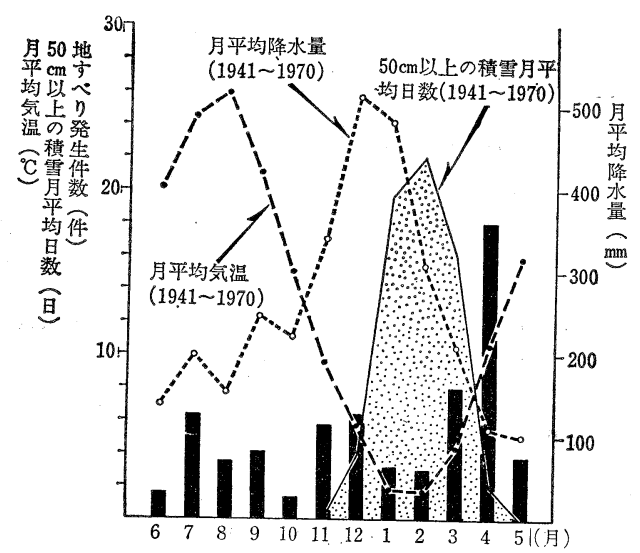

図-2 地すべり発生件数と気象（高田）

地すべり発生件数は1949 1973年の新潟県に㧍ける月別発生件数であ り, 気象 (高田) は理科年表による。

年間) 数と気象 (高田測候所観測 $)^{4)}$ との関係は図 - 2 に示すごとくである。これらでみると, 地すべりの発生 頻度は 4 月に最も高く，7月之 12 月にも高まる。これら の時期は，それぞれ最多融雪期，梅雨後期抢よび冬型の 気圧配置による降雨と融け易い積雪期に一致している。 年間に発生する地すべりのうち $40.3 \%$ は融雪期（ 3 月， 4月）に発生している。したがって, 融雪期は新潟県の 地すべりの発生機構を解くのに重要な時期といえよう。
図一 2 には平均降水量を月別にプロットしたが，夏から 秋（ 5 月～11月）の降水量と発生件数は，ほぼ比例的な 変化をみせる。しかし，冬から春（12月～4月）では, 降水量と発生件数はむしろ反比例的でさえある。地すべ りの発生は, 降水が地下へ浸透することによって誘発さ れるとすれば，夏から秋にかけての降水と地すべり発生 との関係は容易に理解できる。冬（12月～2月）には多 量の降水はその多くが積雪として残る。そして春 ( 3 月, 4月）の気温の上昇に伴ら急激な融雪水は, 地表から地 下へと供給される。このことが融雪期に地すべりの発生 を集中させていると推定できる。この推定が正しければ, 急速に融ける時期の積雪（ 3 月の積雪）が深い年ほど融 雪水は多量で, 融雪期間の地すべりの発生頻度は高くな るはずである。

困 - 3 は, 1953年から1974年の 22 年間の各年 3 月の最 大積雪深 (観測地 : 東頸城郡安塚町 ${ }^{5)}$ と, その年の融雪 期（3月，4月）に和ける地すべり発生件数を表したる のである。図-4にはその相関関係を示すが，これでみ ると拈り多少のバラッキはあるものの明らかに両者の相 関，すなわち急速に融け易い積雪深が大きい年ほど地す ベりの発生が多いことを認める。よって新潟県に拊ける 地すべりは, 融雪水に誘発されて発生するものが多いと 理解してよい。 


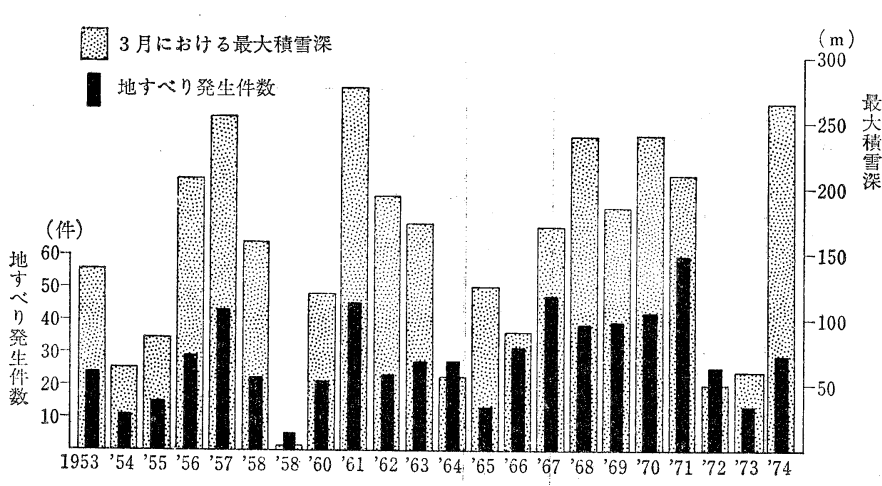

図-3 3 月の最大積雪深（安塚町）とその融雪期 ( 3 月, 4 月) に発生した地 ナベり件数

最大積雪深は新潟県農業気象月報による（1961年は 4 月に最大積雪深がある融雪期は 5 月 まで及んだので 5 月の発生件数も含めてある)

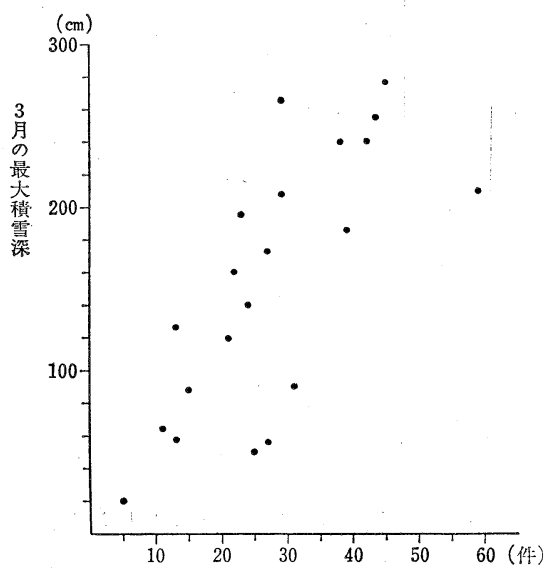

図-4 3月（1961 1974）の最大積雪深（安塚町） とその融雪期（ 3 月，4月）に発生した地すべ り件数との関係

ところで，今年（1974年） 4 月 5 日から11日の 1 週間 に新潟県新井市平丸地区といら限られた地域で，ここは 同一の地質（黒色泥岩）よりなるが，異なった沢を中心
に地すべりが群発した。ここでの気象と地 すべりとの関係を図ー5 に示し，今後地す ベり発生と気象との関係をより精密に解く 鍵としたい。

以上，気象と地すべりとの関係について 述べたが，特にその発生には，新潟県特有 の気象条件が強い影響を与えていることを 強調して拉きたい。

\section{4. 地殼変動と地すべり}

地すべりは，重力の作用による地表の平 坦化 (安定化) 現象の 1 つであり, 地殸の 不均一な運動によって生ずる地表の高低差 が第一義的な要因である。したがって, 単 位区域内で地殼変動量の差が大きい所汇ど平坦化（安定 化）のエネルギーは大きいはずである。ただし,「平坦化 （安定化）作用」が地すべり現象となるか，あるいは崩 壊現象として表現されるかはその場所の諸因子によって 異なるであろう。いう屯でもなく，地すべりとしての侵 食作用も地殼の侵食輪迴のらちの一現象である。この輸 趈が続くには，侵食の場と堆積の場が存在し，前者は隆 起，後者は沈降現象をそれぞれ伴うはずである。新潟県 の場合, 図-6 に示すごとく地㪍変動が考兄られてい る ${ }^{6)}$ 。新潟県の地すべりはすべて隆起地区内にある。特 に 250 500m*，500 750m の隆起区分内の地すべりは 1291地区あり, 地区数で全地すべり地区の $81 \%$, 面積で $82 \%$ 占めている。これらの区域程度の隆起が地すべり を起し易いか否かは今後の問題として検討したい。ただ し，地殼変動は地殻のバランス運動であり，数百年，数 千年のオーダーでー変するものではなく, 地質年代的オ ーダーで持続するものである。とすると, 現在程度の地 形のバランスを保ちつつ，侵食が進むと仮定した場合，

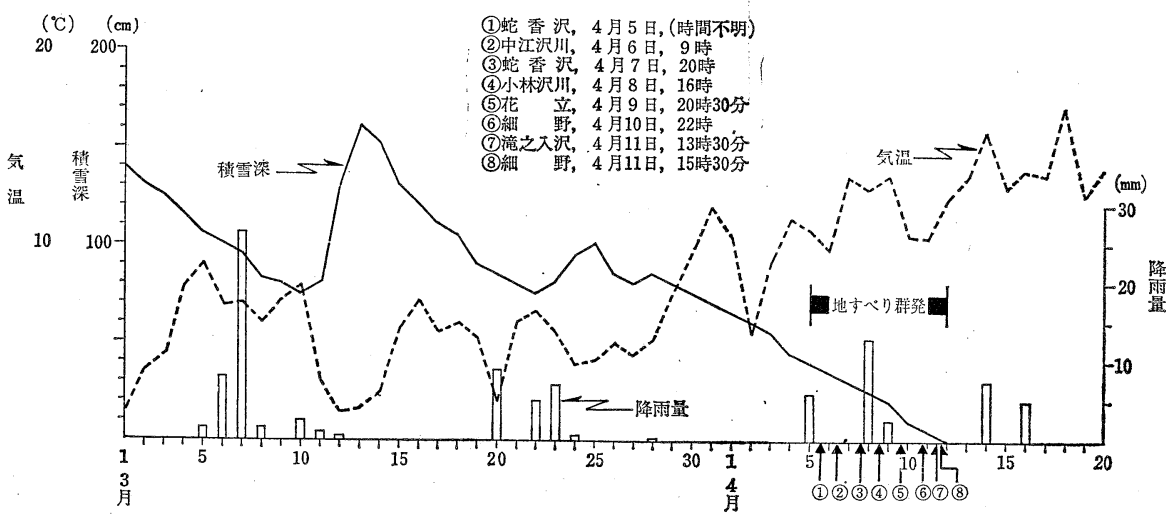

図-5 1974年の融雪期に新潟県新井市平丸地区で群発した地すべりと気象との関係 積雪深, 気温は平丸小学校, 降雨量は新井砂防事務所のそれぞれの観測資料に上る 


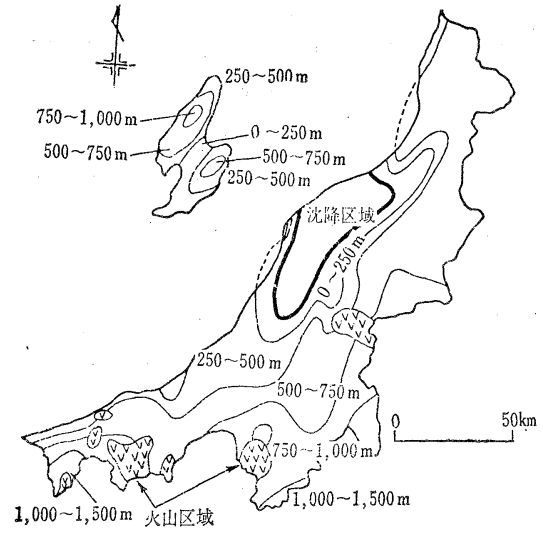

図-6 新潟県の地殼変動量図（第四紀地殼変動グループ, 1969による)

変動量は第四紀の期間（約200厅年）内でのものである

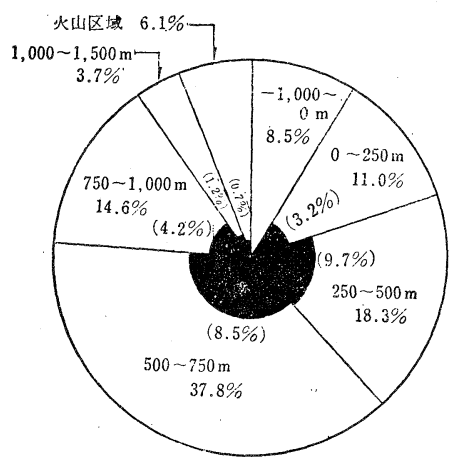

図-7 新潟県の地殼変動量区分の構成とその中に占める 地すべり地区の割合

各地殼变動区分内から堆積の場に向って新たに外に出る 土量は, 単純に計算して表一 3 に示すとおりである。地 すべり地区の割合が多い250～500m，500～750m の区分 内では，年間 $22.9 \times 10^{5} \mathrm{~m}^{3}$ の土が完全にこれらの区域外 に出ることによって，現在のような地形のバランスが保 たれると理解する。この土量は全体（火山区域を除く） の約 6 割に当る。したがって，上記仮定が正しければ， これらの区域では多くの德食量が要求されている所でも ある。そして現実に図－7に示すよらに，250～500m 区
域ではその $9.7 \% か ゙ ， 500 〜 750 \mathrm{~m}$ の区域では 8.5\%がそ れぞれ地すべり地区となって扔り，他の区分域と比べて 著しく高い。よって, 新潟県に括けるこれらの区域は, 初期の侵食作用として地すべり現象の占める役割が大き いと考光たい。このような地殼变動, すなわち「侵食の 場」「堆積の場」が存在するといら自然界の認識は, 地 すべり防止対策のみならず, 広く，治山，砂防，河川， そして海岸等の対策に共通する基礎であることを付言し て执きたい。

な特，本報告で扱った地殼変動よりわオーダーの小さ い地域的な変動, たと衤ば小規模な活褶曲, 活断層など はその地域の地べりとの関係を一層精密に観察さる心要 があろら。

\section{5. 地質と地すべり}

新潟罧の地質は，その概要を図-8に示すように，系魚 川一静岡構造線以西は主として中·古生層が, 魚野川一 破間川一村上を結んだ線以東は主として火成岩類, 中。 古生層が分布し, それぞれ急峻な地形を呈している。こ れらに対し, 上記構造線の内側は新生代（新第三紀，第 四紀）の地層が広く分布し，山地ないしは丘陵执よび平 野地形を呈している。図-1と図-8を対比してみると，地 すべり地区は主として新第三紀層の分布する地域に多い ことがわかり, 地すべりと地質との関係が密接であるこ とが容易に予想される。そこで，地質と地すべり地区と の関係を定量的に扱うことにする。な执，新潟県の新生 代の標準層序表を表-4に揭げて捈く。

\section{5-1 地層との関係}

地すべりと地層との関係は表-5に示した。これでみる ように, 各地質区分内で占める地すべり地区の面積と地 区数の率はほぼ同様であるので, 地すべり地区面積と地 層との関係で述べる。な报, 一部の地域で椎谷層か寺泊 層かで見解の一致をみない泥岩層があるので，ここでは 両者を合わせて椎谷 : 寺泊層とした。

図-9は，新潟県の地すべり地区がいかなる地層の所に 多いかを表したものである。これでみると，椎谷・寺泊 層の地すべり地区が全体の $43.2 \%$ 占め, 西山層のもの

表-3＼cjkstart地すべりと地殼変動量との関係

\begin{tabular}{|c|c|c|c|c|c|c|c|c|c|c|}
\hline \multirow[b]{2}{*}{ 区 } & \multicolumn{2}{|c|}{ 地 } & べ & \multicolumn{2}{|c|}{ 区 } & \multirow[b]{2}{*}{ 全 } & \multirow[b]{2}{*}{ 倩 } & \multirow{2}{*}{$\begin{array}{l}\text { 地すべり } \\
\text { 地区面積 } \\
\text { の占有率 }\end{array}$} & \multirow{2}{*}{\multicolumn{2}{|c|}{$\begin{array}{l}\text { 現地形のバランスを保 } \\
\text { つに必要な土量の移動 }\end{array}$}} \\
\hline & 地 & 数 & 面 & 積 & $\begin{array}{l}1 \text { 力所当 } n \\
\text { の平均面積 }\end{array}$ & & & & & \\
\hline$-1,000 \sim 0$ & 0力所 & $-\%$ & Oha & $-\%$ & -ha & $1,075 \mathrm{~km}^{2}$ & $8.5 \%$ & $-\%$ & $-\times 10^{5} \mathrm{~m}^{3}$ & $-\%$ \\
\hline $0 \sim 250$ & 148 & 9.3 & 4,428 & 5.8 & 29.9 & 1,381 & 11.0 & 3.2 & 0.9 & 2.9 \\
\hline $250 \sim 500$ & 485 & 30.4 & 22,357 & 29.5 & 46.1 & 2,300 & 18.3 & 9.7 & 4. 3 & 13.9 \\
\hline $500 \sim 750$ & $8^{-\infty}$ & 50.6 & 40,210 & 53.0 & 49.9 & 4,754 & 37.8 & 8.5 & 14.8 & 47.9 \\
\hline $750 \sim 1,000$ & 132 & 8.3 & 7,780 & 10.3 & 58.9 & 1,840 & 14.6 & 4.2 & 8.1 & 26.2 \\
\hline $1,000 \sim 1,500$ & 11 & 0.7 & 553 & 0.7 & 50.3 & 460 & 3.7 & 1.2 & 2.8 & 9.1 \\
\hline 火山区域 & 11 & 0.7 & 547 & 0.7 & 49.7 & 767 & 6.1 & 0.7 & & \\
\hline 計 & 1,593 & 100.0 & 75,875 & 100.0 & 47.6 & 12,577 & 100.0 & 6.0 & 30.9 & 100.0 \\
\hline
\end{tabular}




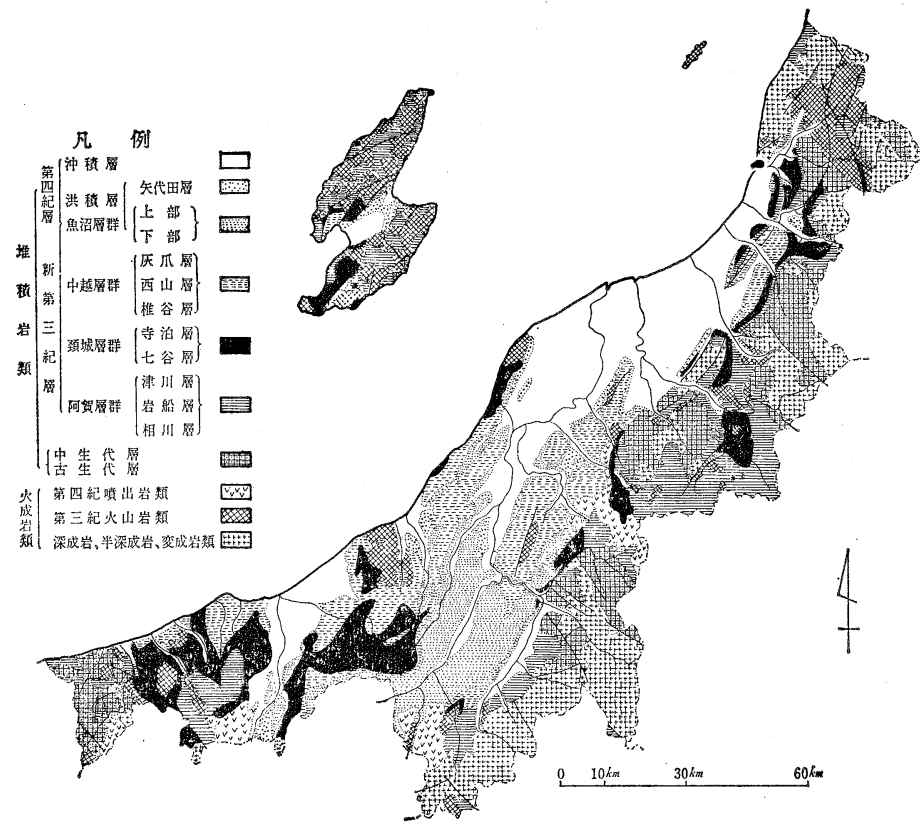

図-8 新舄県 の地質概要図

表 - 4 新潟県の新生代の標準層序表

\begin{tabular}{|c|c|c|c|}
\hline \multicolumn{2}{|c|}{ 地質時代 } & 地層名 & 主な岩 石 \\
\hline \multirow{2}{*}{$\begin{array}{l}\text { 第 } \\
\text { 䋟 } \\
\text { 縚 }\end{array}$} & \multirow{2}{*}{ 更新世 } & 矢代田層 & 砂, 砵, 粘土 \\
\hline & & 魚沼層群 & 砂, 磪, 粘土. 砂·矽·粘土互層 \\
\hline \multirow{8}{*}{$\begin{array}{l}\text { 新 } \\
\text { 第 } \\
\text { 三 } \\
\text { 紀 }\end{array}$} & \multirow[t]{2}{*}{ 鮮新世 } & 灰瓜層 & 細粒砂岩, シルト岩, 砂岩・シルト岩互層 \\
\hline & & 西山層 & 兏色泥岩，砂岩泥岩互層 \\
\hline & \multirow{6}{*}{ 中新世 } & 椎谷層 & 喑灰色泥岩（いわゆる黒色泥岩），泥岩・砂岩互層 \\
\hline & & 寺泊層 & 黒加っ色泥岩（いか内る黑色泥岩） \\
\hline & & 七谷層 & 黑色～灰色硬質泥岩，凝灰岩 \\
\hline & & 津川層 & 緑色凝灰岩, 砂岩・泥岩・䂿岩 \\
\hline & & 岩船層 & 緑色凝圧岩・安山岩・石英安山岩・石英粗面岩・硬質泥岩・磞岩 \\
\hline & & 相川層 & 変質安山岩・石英粗面岩・凝灰角磻岩・珪質頁岩・磁岩 \\
\hline
\end{tabular}

表-5 地すべりと地質との関係

\begin{tabular}{|c|c|c|c|c|c|c|c|c|}
\hline \multirow[b]{2}{*}{ 区 } & 地 & $す$ & べ & 地 & 区 & \multirow[b]{2}{*}{ 面 } & \multirow[b]{2}{*}{ 皘 } & \multirow{2}{*}{$\begin{array}{l}\text { 地すべり } \\
\text { 地区面積 } \\
\text { の占有率 }\end{array}$} \\
\hline & 区 & 数 & 面 & 皘 & $\left|\begin{array}{l}1 \text { 力所当り } \\
\text { の平均面積 }\end{array}\right|$ & & & \\
\hline 沖積層·洪積層上部 & 0力所 & $-\%$ & Oha & $-\%$ & - ha & $313,169 \mathrm{ha}$ & $24.9 \%$ & $-\%$ \\
\hline 魚 沼 層 群 & 301 & 18.9 & 13,582 & 17.9 & 45.1 & 93,070 & 7.4 & 14.6 \\
\hline$\pi$ & 127 & 8.0 & 4,628 & 6.1 & 36.4 & 44,020 & 3.5 & 10.5 \\
\hline 西山 & 285 & 17.9 & 13,885 & 18. 3 & 48.7 & 49,051 & 3.9 & 28.3 \\
\hline 椎 谷·寺 泊 層 & 618 & 38.8 & 32,778 & 43.2 & 53.0 & 94,328 & 7.5 & 34.7 \\
\hline 七 谷·津 川 層 & 107 & 6.7 & 4,401 & 5.8 & & 123,255 & 9.8 & 3.6 \\
\hline 岩 船·相 川 層 & 78 & 4.9 & 3,794 & 5.0 & 48.6 & 98,101 & 7.8 & 3.9 \\
\hline 中·古＼cjkstart生 & 13 & 0.8 & 683 & 0.9 & 52.5 & 118,244 & 9.4 & 0.6 \\
\hline 火山 岩 類 & 40 & 2.5 & 1,745 & 2.3 & 43.6 & 103,132 & 8.2 & 1.7 \\
\hline 深成孷類·诚岩深成岩 & 24 & 1.5 & 379 & 0.5 & 15.8 & 221,356 & 17.6 & 0.2 \\
\hline 計 & 1, 593 & 100.0 & 75,875 & 100.0 & 47.6 & $1,257,706$ & 100.0 & 6.0 \\
\hline
\end{tabular}

が18.3\%，魚沼層群のものが17.9\% とつづいている。また，上記を含め た第三紀層（魚沼層群も含む）の地 すべりは $96.3 \%$ を占め, 新潟県の地 すべりはほとんど第三紀層の地すべ クである。

すでに述べたように，新潟県の地 すべりは椎谷・寺泊層の中に形成さ れるものが著しく多いといえる。し かし, このことから, 椎谷・寺泊層 は地すべりを形成し易い地層である とすることはできない。なぜなら， 仮に新潟県に分布する地層のらち, 椎谷·寺泊層の占める割合が著しく 多ければ，たと光，地すべり地区が 各地層に均等に分布していても，椎 谷·寺泊層に多くの地すべりが存在 しているようにみ觉るからである。 そこで新潟県（1962）の $1 / 20$ 万地質 図から各地質区分の地表面積を求め, これらの中で地すべり地区の占くる 割合を算出してみた（表-5)。図-10 にこの結果を示すが，これでみる上 抒り椎谷・寺泊層ではその $34.7 \%$ が 地すべり地区で, 次いで西山層の 28 $.3 \%$ が，魚沼層群の $14.6 \%$ そ，そし て灰爪層の $10.5 \%$ がれぞれ地すへ り地区となっている。地すべり地区 の占有率の高低は, 各地層が地すべ り地区となり易いか否かの尺度と考 えてよい。したがって, 椎谷・寺泊 層は, 新潟県では最も地すべり地区 となり易い地層である。また，同じ 新第三紀の地層でも，七谷・津川層, 岩船・相川層はそれぞれ $3.6 \% ， 3.9$ \%と，地すべり地区となりにくい地 層といえる。そして, 中·古生層, 火山岩類, 深成岩類, 半深成岩類で は新潟県の場合, ほとんど地すべり 地区とならないことがわかる。 各地層に属する地すべり地区の

1 力所当りの平均面積は表- 5 に示 すように椎谷・寺泊層中のものが最 大で53. 0ha, 次いで西山層, 中.古 生層に属するものが $48.9 \mathrm{ha}$ となって おり, 火成岩類や変成岩類中のもの は他と比べて著しくせまい。

\section{5-2 地質構造との関係}




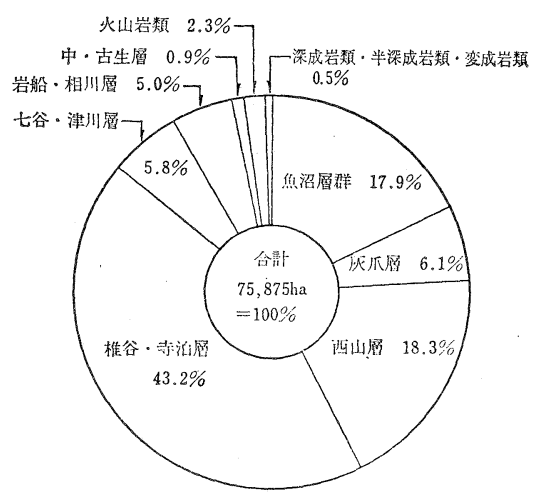

図-9地すべり地区の地層別割合

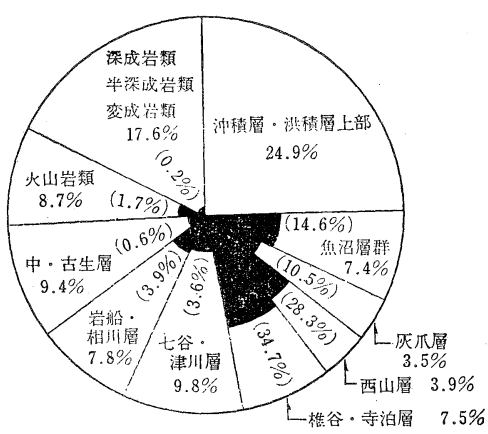

図-10 新潟県の地質区分の構成とその中に占める 地すべり地区(黒色)の割合

地質構造と地すべりとの関係の検討は, 次の上うに行 なつた。すなわち，背斜構造拉よび向斜構造として分類 した地すべり地区之は, 地区内の地層の傾斜が場所によ って著しく異なるもので, 前者はとれが背斜構造による もの，後者は向斜構造によるものである。単斜構造とし たものは，地区内での地層の傾斜が大きく異ならない所 である。断層として分類したものは, 地区内に断層が存 在するか，または周辺のそれにより著しく地層の変形が あると考光られる地区である。そして, 迸入岩体とは，地 区内，または近接して大貫入岩体がある地すべり地区で ある。な㜿，褶曲構造と断層構造が重複する箇所があっ たが，これに該当する地区は断層構造を優先させて分類 した。また，火成岩地帯，あるいは堆積岩地带であって も，上記のような地質構造との関係が不明確な地区は除 外した。その結果を図-11に示す。このグラフでは, 外 側は地区数，内側は面積をそれぞれの比率で表した。眓 に示すごとく，地すべり地区の70\%は単斜構造をなす地 区にあり，背斜構造の地区に $14 \%$, 向斜構造の地区では $10 \%$ とっている。そして, 地すべり地区の地質構造が 断層の影響を強く愛けている所は約 6 \%である。迸入岩 体として分類される地すべり地区は $0.5 \%$ を占めるにす ぎない。このように新潟県の地すべり地区の多くは単斜 構造の地区内にあるとい方よう。このことは, 従来から

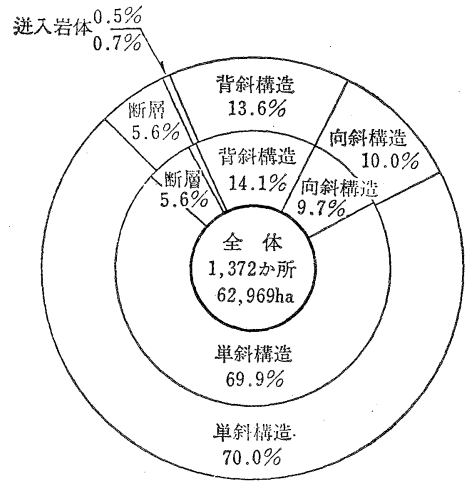

図-11 地すべり地区の地質構造医分 グラフの外側は地区数, 内側は面積

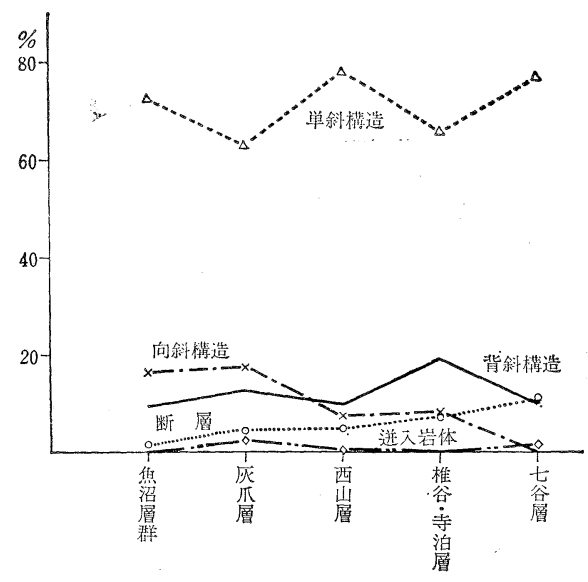

図-12 各地層別にみた地すべり地区と地質構造

の地すべりは褶曲構造や断層, あるいは羊入岩体の周辺 飞頻発しているという見解勇,87,99,100,11) とは異なった結 果となっている。この相違は, 従来の見解は主として, 褶曲断層等が顕著に発達する地域泿って扱った結果で あるのに対し，本報告では，新潟県全域の地すべり地区 を対象としているからであるら。ただし，褶曲軸や断層 等は地質図上では線で表現できるように, これらの構造 線の影響が強い周辺の面積は，全体からみれば極めてせ まい範囲である。にもかかわらず，地すべり地区面積で 約 $30 \%$ もがこのような地帯にあるという筆者らの結果か らも確がかかる地質構造の所では地すべり地区が密に 形成され易いと理解してよい。しかし，新潟罧全体から 久た場合, 単斜構造の地域にもかなりの地すべり地区が あることを再度述べて扣きたい。

次に，図一12は各地層ごとに地質構造と地すべりとの 関係を表した図である。この図から，古い時代の地層ほ ぞ向斜構造に属する地すべり地区の率が少なくなり，断 層周辺のものは逆増加する傾向を認める。これらのこ とは，新潟地域の造構造運動の発達史にかかわる問題に 
も関連するので，ここでは上記現象を記述するにとどめ たい。

なお，図-12では津川層，岩船層・相川層および中・古 生層が分布する地域での地すべり地区については，他と の比較にたえるデータ数に満たないので省いた。

\section{5-3 走向・傾斜と地すべり}

図ー13は, 地すべりとそこの地層の走向・傾斜との関 係が明確な地区1245力所（面積：57, 569ha）飞ついて, 地すべり方向と走向・傾斜との関係を求めたものである。 ここで, 流机盤すべりとは, 地すべりの方向とそこの地 層の傾斜方向とがほぼ一致するもので，その逆が受け盤 すべりとして，それぞれ扱った。そして，すべり方向が 走向方向に扮物を称一致するものは走向地すべりとして 分類した。図-13に示すよらに，流れ盤すべり地区と走 向地すべりの地区は，いずれも約 $40 \%$ を占め，受け盤す ベりの地区は約 $20 \%$ と，前 2 者に比べて低い。

図一14は，各地層に分布する地すべりの地区が，それ ぞれどのような割合で, 流れ盤, 受け盤, 走向すべりと なっているかを表したものである。魚沼層群では約 $60 \%$ が流机盤すべり，約30\%が走向すべりとなっている。灰 爪層では, 流れ盤すべりの地区が約 $48 \%$, 走向すべりのそ れが36\%, 受艋すべりのものは約16\%である。西山層 に属する地区のうちでは約39\%が走向すべりであり, 流

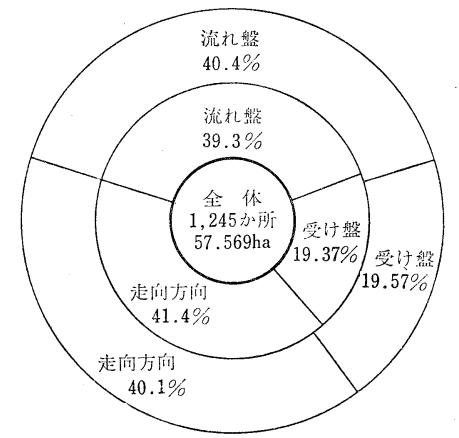

图-13 地すべりの方と地層の走行傾斜との関係 グラフの外僓は地区数, 内側は面皘

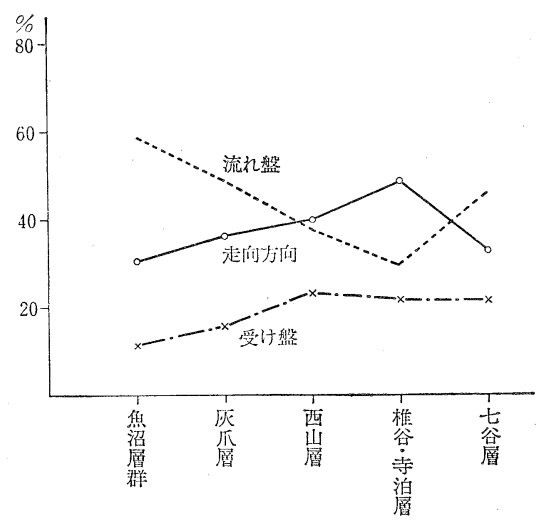

図-14各地層に分布する地すべり地区のすべり方向の割合
れ盤すべりは約38\%，受け盤すべりのそれは23\%となっ て和り，走向すべりが受け盤すべりの割合をわずかに上 回っている。この傾向は椎谷・寺泊層での地すべり地区 に执いてさらに著しくなっている。椎谷・寺泊層に括け る地すべり地区では約50\%が走向すべりであり, 流れ盤 すべりは約 $30 \%$ \%ある。七谷層では再度流れ盤すべりの 地区の率が高くなる。

以上述べたように, 魚沼層群から椎谷・寺泊層までは 地質時代が古くなる注ど走向すべりの割合が増し，流れ 盤すべりの占める割合は低くなるが，七谷層はこの傾向 にない。また，受け盤すべりの地区はいずれの層でる低 率である。

\section{6. 地形と地すべり}

\section{6-1 谷密度との関係}

地すべりと谷密度との関係は表-6にまとめた。また， 地すべり地区が谷密度区分のどの段階区分に多いかは, 図-15に示した。これで明らかなように，地すべり地区 （面積）の約40\%は谷密度が21 25の区域に，27\%が16 〜20の区域に，そして21.5\%が26〜30の区域にあり，こ れらを合わせると地すべり地区の $90 \%$ 近くが谷密度16〜 30の区域に存在することになる。図-16は新潟県全域に 拈ける谷密度区分の面積の割合とその中で占める地すべ り面積の割合を表現したものである。この図でみるとお り，谷密度21～25の区分域内では，その $9.7 \%$ が地すべ

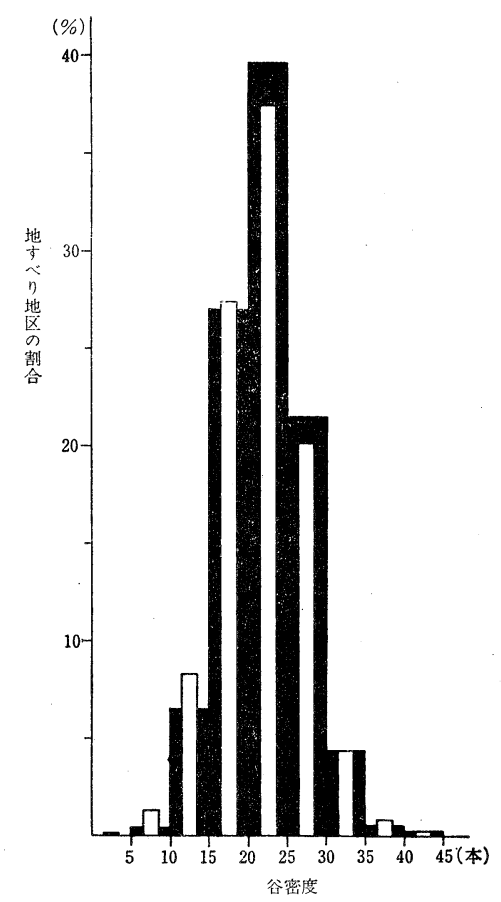

図-15 各谷密度区分に属する地すべり地区の割合 白は地区数, 黒は面皘 
地すへりり Vol. 11，No. 2 (通巻 第38号)

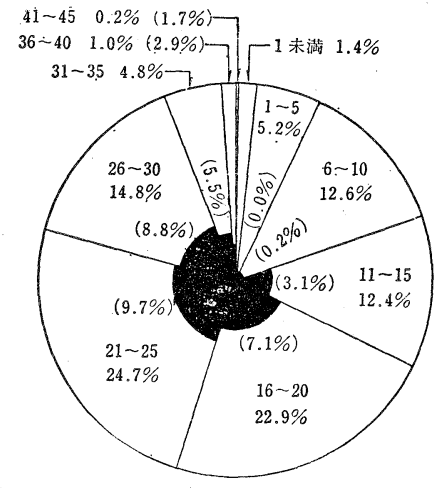

図-16 新潟県の谷密度区分の構成とその中に 占める地すべり地区（黒色）の割合

り地区であり，26〜30では 8.8\%，16〜 200区分域内では $7.1 \%$ がそれぞれ地す ベり地区となっている。また谷密度が低 い10以下の区分域执よび高い36以上の区 域では, 地すべり地区の占有率は非常に 低い。したがって, 地すべり地区が生じ 易い谷密度は16〜30で, これ以外では生 じにくいと理解してよいであろう。

\section{6-2 起伏量との関係}

起伏量と地すべりとの関係は表-7に示 すとおりである。また, 図-17は起伏量の 段階区分とそこに存在する地すべり地区の割合を表した ものである。この図より明らかなよらに, 起伏量が 200 $300 \mathrm{~m}$ の区域内にある地すべり面積は全体の約 $40 \%$ と最 も高く, 次いで300〜400m の $25.1 \% ， 400 \sim 600 \mathrm{~m}$ の 17.6 \%とつづいている。そして,これらの 3 地区に属するもの は全地すべり地区面積の 8 割をこえる。図-18は新潟県 全体の面積の中で起伏量区分の割合とそのそれぞれの区 分内に占める地すべり地区の率を示したものである。こ れでみると, 起伏量200～300m の区域の17\%が地すべり 地区となっておら,この区分内に最も多くの地すべり地 区がある。そして起伏量の少ない $100 \mathrm{~m}$ 未満, 特よび起 伏量の多い $600 \mathrm{~m}$ 以上のそれぞれの区分域内では，地す ベり地区の占める割合はいずれも $1 \%$ に澫たない。また, 地すべり地区の 1 力所当りの平均面積は表-7に示すと挔 り, 起伏量が増加するほど大きくなる（600～800m では 例外)。

地形は侵食作用によって形成されるものであり，地す ベりは侵食作用の 1 つであるといら観点で図-18を見れ ば，ここで地すべり地区の占有率の高い。起伏量区分の 地形は，地すべ現象によって作られる割合が高いと理 解する。

\section{6-3 傾斜度との関係}

傾斜度と地すべりとの関係は表-8にまとめた。そして,
表-6 地すべりと谷密度との関伭

\begin{tabular}{|c|c|c|c|c|c|c|c|}
\hline 地 & $す$ & ベ & 地 & 区 & & & 地すべり \\
\hline 区 & 数 & 面 & 積 & $\begin{array}{l}1 \text { 力所当 } 0 \\
\text { の平均面積 }\end{array}$ & 全 & 積 & $\begin{array}{l}\text { の占有率 } \\
\text { 地四植 }\end{array}$ \\
\hline 0 力所 & $-\%$ & oha & $-\%$ & Oha & $17,525 \mathrm{ha}$ & $1.4 \%$ & -\% \\
\hline 1 & 0.1 & 18 & 0.0 & 18 & 65,626 & 5.2 & 0.0 \\
\hline 21 & 1.3 & 333 & 0.4 & 15.9 & 158,472 & 12.6 & 0.2 \\
\hline 132 & 8.3 & 4,903 & 6.5 & 37.1 & 156,234 & 12.4 & 3.1 \\
\hline 437 & 27.4 & 20,481 & 27.0 & 46.9 & 288,232 & 22.9 & 7.1 \\
\hline 597 & 37.5 & 30,146 & 39.7 & 50.5 & 310,604 & 24.7 & 9.7 \\
\hline 322 & 20.2 & 16,288 & 21.5 & 50.6 & 184,946 & 14.8 & 8.8 \\
\hline 68 & 4. 3 & 3,271 & 4.3 & 48.1 & 60,033 & 4.8 & 5.5 \\
\hline 13 & 0.8 & 385 & 0.5 & 29.6 & 13,051 & 1.0 & 2.9 \\
\hline 2 & 0.1 & 50 & 0.1 & 25.0 & 2,983 & 0.2 & 1.7 \\
\hline 93 & 100.0 & 75,875 & 100.0 & 47.6 & $1,257,706$ & 100.0 & 6.0 \\
\hline
\end{tabular}

表-7 地すべりと起伏量との関係

\begin{tabular}{|c|c|c|c|c|c|c|c|c|}
\hline \multirow[b]{2}{*}{ 区 分 } & 地 & $\Phi \sim$ & $\eta$ & 地 & 区 & \multirow[b]{2}{*}{ 全 } & \multirow[b]{2}{*}{ 積 } & \multirow{2}{*}{$\begin{array}{l}\text { 地すべり } \\
\text { 地区面積 } \\
\text { の占有率 }\end{array}$} \\
\hline & 地 & 数 & 面 & 積 & $\left|\begin{array}{l}1 \text { 力所当 } b \\
\text { ○平均面積 }\end{array}\right|$ & & & \\
\hline $0 \sim 50 \mathrm{~m}$ & 2力所 & $0.1 \%$ & 19ha & $0.0 \%$ & 9. $5 \mathrm{ha}$ & $188,656 \mathrm{ha}$ & $15.0 \%$ & $0.0 \%$ \\
\hline $50 \sim 100$ & 16 & 1.0 & 343 & 0.5 & 21.4 & 53,638 & 4.3 & 0.6 \\
\hline $100 \sim 150$ & 99 & 6.2 & 3,068 & 4.0 & 31.0 & 80,271 & 6.4 & 3.8 \\
\hline $150 \sim 200$ & 221 & 13.9 & 7,490 & 9.9 & 33.9 & 82,491 & 6.6 & 9.1 \\
\hline $200 \sim 300$ & 635 & 39.9 & 30,944 & 40.9 & 48.7 & 182,367 & 14.4 & 17.0 \\
\hline $300 \sim 400$ & 346 & 21.7 & 19,028 & 25.1 & 55.0 & 142,787 & 11.3 & 13.3 \\
\hline $400 \sim 600$ & 239 & 15.0 & 13,361 & 17.6 & 55.9 & 265,228 & 21.1 & 5.0 \\
\hline $600 \sim 800$ & 28 & 1.8 & 1,163 & 1.5 & 41.5 & 186,806 & 14.9 & 0.6 \\
\hline $800 \sim 1,000$ & 7 & 0.4 & 459 & 0.6 & 65.6 & 62,145 & 4.9 & 0.7 \\
\hline 1,000 以上 & 0 & - & 0 & - & - & 13,317 & 1.1 & - \\
\hline 計 & 1,593 & 100.0 & 75,875 & 100.0 & 47.6 & $1,257,706$ & 100.0 & 6.0 \\
\hline
\end{tabular}

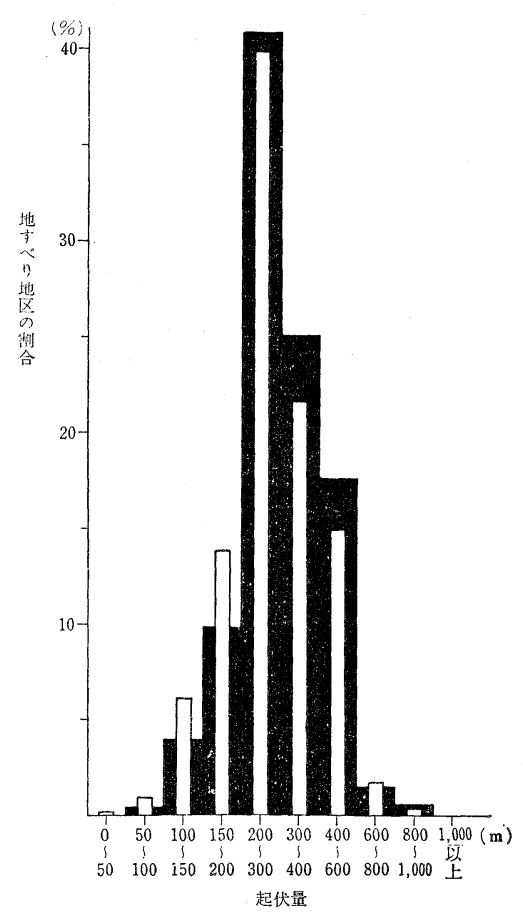

図-17 各起伏量区分に属する地すべり割合 白は地区数, 黒は面積 


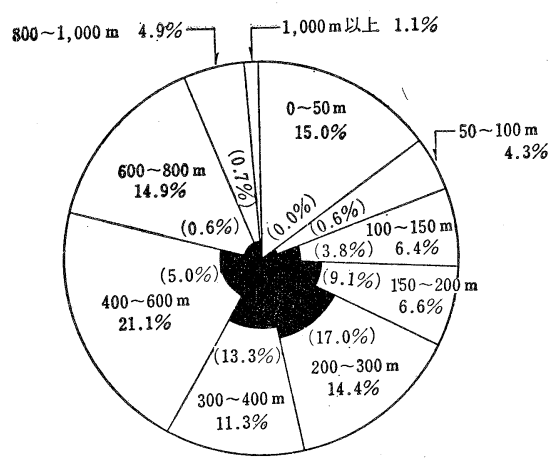

図-18 新潟県の起伏量区分の構成とその中に占める地 すべり地区（黒色）の割合

地すべり地区がいかなる傾斜度の所に多いかを図ー19k 表した。これで示すと特り，地すべり地区（面積）の $43.5 \%$ が $8^{\circ} \sim 15^{\circ}$ の区分域内に， $34.6 \%$ が $15^{\circ} \sim 20^{\circ}$ の域 内にある。この両者を合わせて地すべり地区の 8 割近く が $8^{\circ} \sim 20^{\circ}$ の傾斜区分域内に存在することになる。 た, 新潟県全域からみた傾斜度区分域の面積構成比々, 各傾斜度区分内に占める地すべりの割合を図-20 亿示し た。これで示すごとく， $8^{\circ} \sim 20^{\circ}$ の区分内での地すべり 地区の占有率が特に高く, $8^{\circ}$ 未満, $20^{\circ}$ 以上では著しく 低くなり， $3^{\circ}$ 未満， $30^{\circ}$ 以上では $1 \%$ 以下である。

地すべりをも含めた侵食作用によって地形が造ら机る といら観点で上記のことを解釈すると, 地すべり地区の 8 割近くが傾斜度区分の $8^{\circ} \sim 20^{\circ}$ に属していることは, 地すべり現象によって生ずる地形は $8^{\circ} \sim 20^{\circ}$ のものが注 とんどであるとい光る。な特，馬場・他（1971）は，空 中写真によって得られた新潟県の地すべり地形を傾斜度 との関係で求めている ${ }^{11)}$ 。それによると，地すべり地形 の65\%（約5400ha）は $48^{\circ} \sim 15^{\circ}, 17 \%$ (約1400ha) は $15^{\circ}$ $\sim 20^{\circ}$ の傾斜度の地形にあるという。筆者らのそれは, それどれ43.5\% (約3300ha)，34.6\% (約2600ha) とな っている。ここにみる差は, 地すべり地域の抽出の相違 もあるし，空中写真による地すべり地形がすべて地すべ り地区（地すべり防止区域, 地すべり危険地域）となっ

表-8 地すべりと傾斜度との関係

\begin{tabular}{|c|c|c|c|c|c|c|c|c|}
\hline \multirow[b]{2}{*}{ 区 分 } & 地 & す & $\eta$ & 地 & 区 & \multirow[b]{2}{*}{ 全 } & \multirow[b]{2}{*}{ 積 } & \multirow{2}{*}{$\mid \begin{array}{l}\text { 地すべり } \\
\text { 地区面積 } \\
\text { の占有率 }\end{array}$} \\
\hline & 区 & 数 & 面 & 積 & $\begin{array}{l}1 \text { 力所当り } \\
\text { の平均面積 }\end{array}$ & & & \\
\hline 3度未滿 & 2力所 & $0.1 \%$ & $45 \mathrm{ha}$ & $0.1 \%$ & $22.5 \mathrm{ha}$ & $2,804 \mathrm{~km}^{2}$ & $22.3 \%$ & $0.0 \%$ \\
\hline $3 \sim 8$ 度 & 46 & 2.9 & 1,935 & 2.6 & 42.1 & 571 & 4.5 & 3.4 \\
\hline $8 \sim 15$ & 763 & 47.9 & 33,012 & 43.5 & 43.3 & 1,916 & 15.2 & 17.2 \\
\hline $15 \sim 20$ & 462 & 29.0 & 26,270 & 34.6 & 56.9 & 1,614 & 12.8 & 16.3 \\
\hline $20 \sim 30$ & 294 & 18.5 & 13,303 & 17.5 & 45.2 & 2,515 & 20.0 & 5.3 \\
\hline $30 \sim 40$ & 25 & 1.5 & 1,303 & 1.7 & 52.1 & 2,966 & 23.7 & 0.4 \\
\hline 40以上 & 1 & 0.1 & 7 & 0.0 & 7 & 194 & 1.5 & 0.0 \\
\hline 計 & 1,593 & 100.0 & 75,875 & 100.0 & 47.6 & 12,580 & 100.0 & 6.0 \\
\hline
\end{tabular}

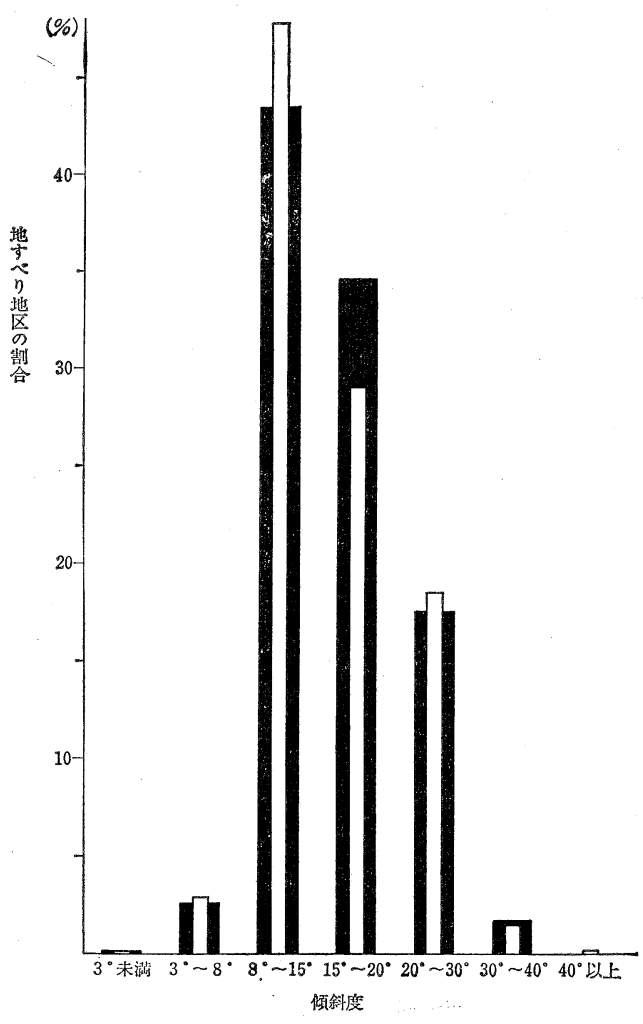

図-19 各傾斜度区分に属する地すべり地区の割合 白は地区数, 黒は面皘

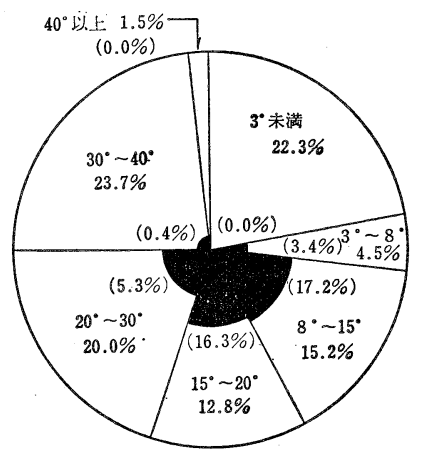

図-20 新潟県の傾斜度区分の構成とその中に占め る地すべり地区（黒色）の割合

ていないことにもよる。な物, データの 集計に当って， $8^{\circ} \sim 15^{\circ}$ に属する地すべ り地区は東頸城地方のいわゆる黒色泥岩 地域に多く, $15^{\circ} \sim 20^{\circ}$ のそれは魚沼地 方, 西頸城地方の比較的粗粒な岩質の所 に多いことに気付いた。これについては 今後詳しく検討してみたい。 


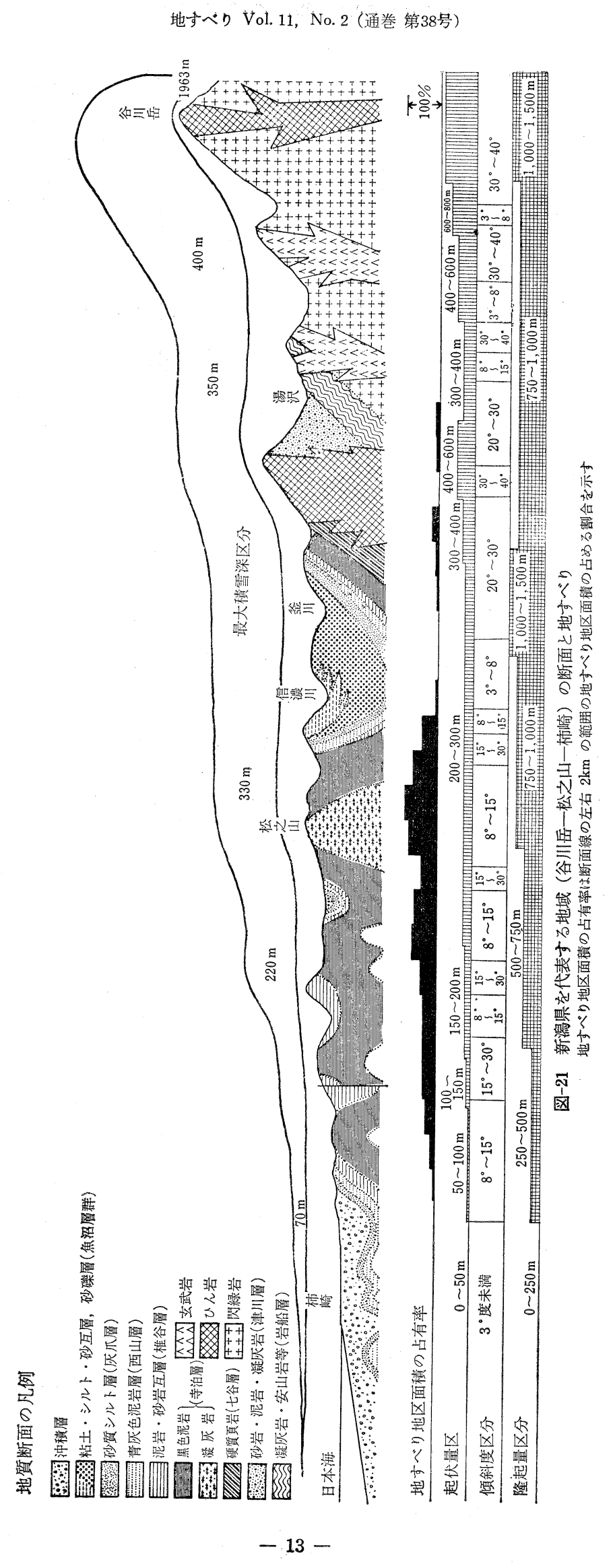




\section{7. まとめ}

新潟県は県土の $6 \%$ \%地すべり地区となっでり, 過 去の記録にあるように，古くから地すべりによる多くの 被害を受けてきた。現在でも, 融雪期には各地で地すべ りが多発している。このような新潟県地域を全国的な視 野でみる々，第四紀地款変動区分の勾配が急な所の $1 つ$ であり，第三紀から第四紀の比較的軟弱な地層が分布し ている地域であり, さらに新しい時代の造構造運動の激 しかった区域でもある。そして, 現在でも地殼変動は継 続しているはずであることを重視したい。また, 新潟県の 地すべりは新生代の地層中のるのがほとんどであるが， 特に第三紀中新世の椎谷. 寺泊層といらいわゆる黒色 泥岩を主体とした岩質の地層に集中している。地層の走 向・傾斜と地すべり方向との関係では, 流れ盤拉よび走 向すべりが多く, 受け盤すべりは少ない。そして, 褔曲 や断層等, 地質構造が複雑な所で地すべり地区は密では あるが，単斜構造の区域にも多くの地すべり地が存在す る。地形との関係では, 谷密度が16〜30の区域で地すべ り地が形成され易い。地すべり現象が侵食作用の 1 つと して地形を造るといら観点では, 地すべりによる侵食は 起伏量200 600m の地形扰よび傾斜度 $8^{\circ} \sim 20^{\circ}$ の地形を 造り易いと考光る。これら新潟県の地すべりと, その自 然環境を代表する谷川岳一松之山一柿崎の断面を図 -21 に示す。

本報告では，地すべりと個々の因子との関係を個別に まとめたが,われわれは，これらの成果を地すべりの単な る「静的な分類」に供するつもりはない。なぜなら, 個 々の因子が地すべり運動といかなる関連にあるのかとい ら課題を解くのに結びつかね枚地すべり防止対策の基礎 としては意味がないからである。すでに，布施（1969， 1974）は時間の観念を導入して地すべりを動的に扱って いるし ${ }^{13) 14}$ ，山野井（1973）は個々の地すべりが進化発 展過程のいずれにあるのかを骨子として扱らべきである ことを指摘している ${ }^{15)}$ そして,これらのことは, 地すべ りを系統的発生と個体的発生の観点で扱らことにもなる。 植村（1974）の「進化」の考兄に立脚した分類法はこの ことを明確にした点で高く評価されるべき提案であり， 自然の理により一層合致した地すべりの扱い方であうう 16)。われわれはこのような動的な観点で本報告での成果 を生かすつるりである。

最後に, 本報告で扱った個々の因子と地すべりが, 自 然の運動の中でいかに位置付けられるかをフローチャー ト風に図-22 に示し, これを今後の地すべり現象の解明, そして，地すべり対策の思考基礎としたい。

\section{文 献}

1）福本安正（1973）：新潟県内の地すべり災害とその 防止対策, 林業技術, No. 378, pp. 9 13

2),5）新潟地方気象台・新潟県（1953 1973）: 新潟県 農業気象月報

3),6）第四紀地殼変動研究グループ（1969）：集成隆起 沈降量図, 国立防災科学技術センター

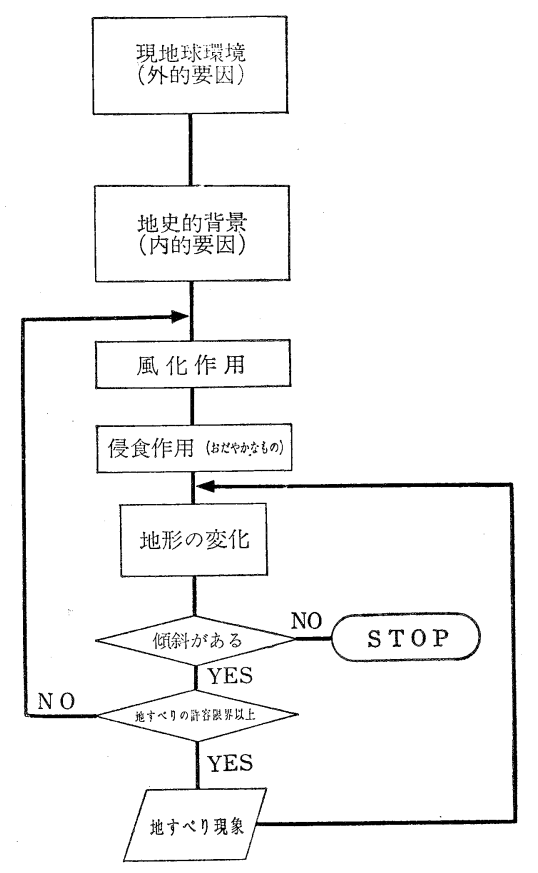

図-22 自然の運動の中にお活る地すべり現象

4）東京天文台（1974）：理科年表, 丸善, 東京

7）高野秀夫（1960）：地すべりと防止工法, 地球出版 社, 東京

8）津田禾粒 - 岩永伸 - 西田彰一（1967）：第三紀層地 すべりと岩質および地質構造との関係——新潟県下 の第三紀層地ず゙りについて—, 災害地質討論会論 文集, pp. 58 70

9）西田彰一・湊元光春（1973）：新潟県に扔ける第三 紀層地スベリの特徵と対策, 土と基礎, Vol. 21, No.7, pp. $5 \sim 11$

10）岩松暉・服部昌樹・西田彰一（1974）：地すべりと 岩石の力学的性質——新潟県山中背斜を例として 一, 地すべり, Vol. 11, No. 1, pp. 13〜20

11），14）布施弘（1974）: 新潟県の黒色泥岩地域にみら れる地すべりの発生と発展について, 新潟応用地質研 究会誌, Vol. $21 \sim 22$, pp. $42 \sim 49$

12）永田聡・神田章·馬場一雄・須田光治（1974）：新 潟県の地すべり分布と地形について，地すべり，Vol.

11, No. 3, pp. 19 22

13）布施弘（1969）：新潟県の黑色泥岩層にみられる地 すべりの機構, 地すべり, Vol. 5, No. 4, pp.9〜12.

15）山野井徹（1973）：上平丸地すべりについて, 新潟 県治山実績発表会報文集, 第 2 号, pp. 124 132

16）植村武（1974）：地すべり分類の基準について，地 すべりの分類に関するシンポジウム講演論文集, pp. $1 \sim 7$

（原稿受理日 昭和 49 年 9 月 6 日） 